\title{
The BIO software module for an evaluation system of drivers' predispositions
}

\author{
K. Różanowski ${ }^{1}$, Z. Piotrowski ${ }^{2}$ \& M. Bernat ${ }^{2}$ \\ ${ }^{1}$ Aviation Bioengineering Department, \\ Military Institute of Aviation Medicine, Poland \\ ${ }^{2}$ Faculty of Electronics, Military University of Technology, Poland
}

\begin{abstract}
Based on statistical analyses on the causes of road traffic accidents and the biomedical factors directly impacting the driver's behavior, a software module for drivers' predispositions evaluation has been developed.

The module was based on selected biomedical signals registered in real-time during arranged car travel on a route of ca. $400 \mathrm{~km}$. The tests were conducted on a group of 17 people aged 26-45.

The designed and tested Matlab module was eventually migrated to $\mathrm{C}$, enabling compilation and running on a dedicated hardware platform.

The results prove that: the basic physiological parameters differ at the beginning and at the end of a driver's working week; there is a correlation between the driver's age and the average value of the driver's BIO indicator; and that it is possible to assess in real-time the driver's predispositions to continue driving.

The BIO software module shows unprecedented end-to-end approach to evaluating the driver's biomedical condition, based on a broad range of signals. Keywords: driver, road traffic, biomedical signal, software module, driver's predispositions.
\end{abstract}

\section{Introduction}

The physiological condition of vehicle drivers is of key importance for road safety and for the life and health of other users of the roads. A number of external factors may contribute to gradual deterioration of the driver's condition (such as eyesight [1]) and undiagnosed illness may result in abrupt health disorders. This becomes especially important, when we consider the large percentage of road accidents of 
professional drivers in the total number of occupational injuries, workplace absence or workplace deaths [2].

When drawing up a general characteristic of the group causing road accidents, we should highlight the drivers that: disregard traffic regulations, behave irresponsibly, play down speed limits, and most of all, show much recklessness and are prone to drunk driving [3]. Moreover, traffic accident statistics show that drivers aged 15-29 participate in accidents twice as often than those drivers 30 years older [4].

The significant factors related to the road situation and the driver's health condition that affect road safety include:

- fatigue: physical, local, general, "brain" (somnolence), mental, lack of energy - slower reactions, greater number of mistakes, perception disorders, higher aggression levels - symptoms very similar to those of alcohol or psychotropic drug consumption [5]; according to Police statistics [6], fatigue is responsible for less than $1 \%$ of the total number of accidents; according to separate survey research, even $30 \%$ of the drivers experience fatigue (including in extreme form - falling asleep) [7];

- stress - indicating direct connection between the body and the mind - it manifests through increased levels of cortisol and adrenaline, increased heart rate and blood pressure [5], and significantly contributes to cardiovascular disorders [8];

- attention strain - resulting from an excessive number of signals reaching the driver when driving; focusing the attention for a long time is very tiring and is more significant that other factors [9];

- microclimate - this is particularly reflected in the behavior of the neural system and the mental sphere [9];

- distorted vision - dazzling, optical illusions [9], mesopic vision distortion [10];

- decision-making and attention-division processes - the ability to extract significant information from a complex background (perception style), ability to divide attention between various tasks, response time in performing complex tasks [3] - attention distraction is responsible for ca. $40 \%$ of road vehicle accidents [11];

- circulatory system - changes in heart rate that may indicate sleepiness or nervousness of the driver [12], untreated diseases leading to dangerous cardiovascular incidents [13-15].

Scientific research aimed at improving road safety use:

- survey data enabling drawing statistical conclusions based on a large sample [7] (usually big test groups, going in hundreds);

or

- individual physiological signals (such as EEG [16] or HRV [17]), sometimes signal pairs (such as eye movement and driving wheel movement [18] or Galvanic Skin Response (GSR) and photoplethysmography (PPG) [19]), enabling construction of devices detecting characteristic behavior of the driver (usually test groups of several dozen participants). 
The recording and measurement equipment developed by various groups (such as the Multitask physiological and environmental signal monitoring system [20]) lack the functionality of end-to-end evaluation of the collected information.

The aim of study was to develop a software module supporting evaluation of the driver's predisposition to drive the vehicle based on a broad range of symptoms. By using a set of registered biomedical signals (in digital form), the module is to output a normalized, numerical BIO indicator. The tools is to enable continuous analysis and calculation of the indicator in a time shorter than the signal group registration time.

\section{Materials and methods}

\section{Content}

The module for evaluating the predisposition of the driver to drive a vehicle was based on a selection of biomedical signals. The signals were registered in real-time (using the device described in [21]) during arranged test travels, and included: HR (Heart Rate - frequency of heart muscle contractions, extracted from the ECG signal [22]), skin impedance (Imp), arterial blood pressure (systolic - SBPress and diastolic - DBPress), oxygen saturation of the blood (SpO2), body temperature (Temp), and the ability for identify the nature of observed light (CmFlicker for the flicker frequency and CzFlicker for the waning frequency). Measurement sessions took place on a repeatable route of ca. $400 \mathrm{~km}$ (travel time: around 7 hours), with diverse topography and road quality, travelled by each driver on Monday and Friday. The tests were conducted on a group of 17 people aged $26-45$.

The monitored signals had the following parameters (sampling frequency, unit of measure, value range):

- HR: $1 \mathrm{~Hz}, \mathrm{bpm}, 20-255 \mathrm{bpm}$;

- Impedance: $1 \mathrm{~Hz}, 10 \mathrm{kOhm}-200 \mathrm{kOhm}$;

- Arterial blood pressure: every 15 minutes, systolic: $40-250 \mathrm{mmHg}$, diastolic: 20-150 mmHg;

- Saturation: $1 \mathrm{~Hz}, 30-100 \%$;

- Temperature: $25 \mathrm{~Hz}, 15-40^{\circ} \mathrm{C}$;

- Flicker: every 10 minutes, 20-100 Hz.

\section{Approval}

The study received the approval of Human Research Ethics Committee at the Military Institute of Aviation Medicine in Warsaw. All participants signed written informed consent.

\section{Signal processing and component indicator calculation}

The HR, impedance, temperature, blood pressure and flicker signals were filtered out of non-physiological samples and rapid changing components (moving average FIR filter, except for high pressure signal and Flicker). For each sample, NMSE (Normalized Mean Square Error (Fig. 1) [23], An' in Table 1) was calculated, with a variability limited to acceptable physiological values (Table 1) 
and projected onto the $0-1$ range (where 0 is interpreted as the negative extreme, and 1 as the positive extreme).

$$
N M S E=\frac{\sum_{n}\left(A_{n}-A_{n}^{\prime}\right)^{2}}{\sum_{n} A_{n}^{2}}
$$

Figure 1: Normalized Mean Square Error metric.

$$
\text { SpO2_Factor }=\frac{1}{m} \sum_{n=0}^{m-1} \text { SpO2_Factor }_{n}
$$

Figure 2: Blood oxygen saturation factor equation.

$$
\text { SpO2_Factor }_{n}=\left\{\begin{array}{c}
0 \text { for } \text { SpO2 } \in\langle 0,90\rangle \\
0,2 * \text { SpO2 }-18 \text { for } \operatorname{SpO} 2 \in(90,95) \\
1 \text { for } \operatorname{SpO} 2 \in\langle 90,100\rangle
\end{array}\right.
$$

Figure 3: The n-th element of the saturation factor equation.

The An variable in NMSE represents the value of the nth signal sample, while the An' variable - the reference value for this sample.

For the saturation signal, non-physiological components were filtered out and a low-pass filter was applied. In the place of NMSE, the percentage of correct values, using the formula shown in Fig. 2 was calculated. Here, the $m$ value equals AWW (Analysis Window Width) measured in samples. Figure 3 shows the manner of determining the SpO2_Factor for the nth signal sample.

Component indicators (factors) were determined for data packets (AWW), the size of which was determined as the product of the time window width and the sampling frequency (the analyzed signal).

$$
B I O_{A W W}=\frac{1}{8} \sum_{x} x_{-} \text {Factor }_{A W W}
$$

Figure 4: Mean of the BIO coefficient equation for a single analysis window width.

\section{Resulting indicator}

Next, the individual indicators obtained as described above were averages (as shown in Fig. 4, where $\mathrm{x}$ is the group of analyzed signals, i.e. HR, Imp, SBPress, 
DBPress, SpO2, Temp, CmFlicker, CzFlicker), giving a continuous, normalized, numerical indicator of the driver's physiological condition (the sample record of the indicator is shown in the upper part of Fig. 5). In order to visualize the variability trend of the BIO indicator over the entire travel, a low-pass filter was applied (lower part of Fig. 5).

Table 1 describes the manner of interpretation of the BIO indicator's values. It is worth adding that the results 0 and 1 are extremes that are highly improbable (none were recorder during live tests).

Table 1: $\quad$ Reference values and limits for signals.

\begin{tabular}{|c|c|c|c|}
\hline Signal & Reference value (An') & Accepted value & Notes \\
\hline Flicker & $60 \mathrm{~Hz}$ & $20-100 \mathrm{~Hz}$ & [29] \\
\hline Heart rate & $75 \mathrm{bpm}$ & $60-90 \mathrm{bpm}$ & [12] \\
\hline Impedance & $200 \mathrm{kohm}$ & $10-200 \mathrm{kohm}$ & [9] \\
\hline $\begin{array}{l}\text { Systolic blood } \\
\text { pressure }\end{array}$ & $0.5 *$ age +105 & $140 \mathrm{mmHg}$ & {$[30]$} \\
\hline \multirow{2}{*}{$\begin{array}{l}\text { Diastolic blood } \\
\text { pressure }\end{array}$} & $\begin{array}{l}0.2 * \text { age }+70.4 \\
\text { (age: } 18-48 \text { years old) }\end{array}$ & \multirow{2}{*}{$90 \mathrm{mmHg}$} & \multirow{2}{*}{$\begin{array}{l}{[14]} \\
{[26]}\end{array}$} \\
\hline & $\begin{array}{l}-0.23 * \text { age }+91 \\
\text { (age: } 48-70 \text { years old) }\end{array}$ & & \\
\hline $\mathrm{SpO} 2$ & $\begin{array}{l}>95 \% \text { - correct } \\
>90 \% \text { - semicorrect }\end{array}$ & $90-100 \%$ & [28] \\
\hline Temperature & $33^{\circ} \mathrm{C}$ & $32-37^{\circ} \mathrm{C}$ & {$[31,27]$} \\
\hline
\end{tabular}

\section{Correlation of the BIO indicator values with road conditions}

The obtained values of the BIO indicator and its components were subdivided into two groups: for results from the beginning of the working week (Monday), and for results from the end of the working week (Friday). The averages for those result groups (including relevant standard deviation) are shown in Fig. 6. The $\mathrm{X}$ axis corresponds to the resulting $\mathrm{BIO}$ indicator and component indicators: CmFlickerFactor, CzFlickerFactor, HrFactor, ImpFactor, SBPFactor, DBPFactor, SpO2Factor and TempFactor. The Y axis shows their corresponding normalized values. 




Filtered BIO live coefficient: AD27

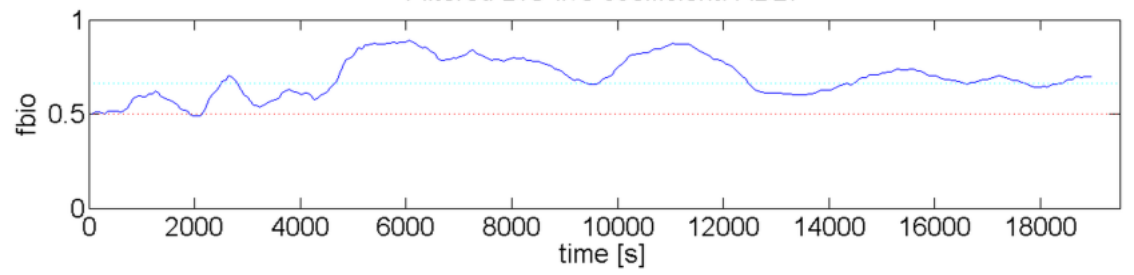

Figure 5: Example of the BIO live coefficient and low pass filtered BIO live coefficient.

\section{Correlation of the BIO indicator values with the driver's age}

To visualize the correlation between the BIO indicator and the driver's age, the value of the indicator for the entire $400 \mathrm{~km}$ route was averaged (separately for each participant). The obtained value has been approximated using a third degree polynomial curve fit (Fig. 7).

\section{BIO software module}

The BIO software module developed and verified in Matlab was migrated to C. The resulting library enables running the module on a mobile platform that stores the recorded signals (Angstrom Linux for ARM CPUs [24]) and on a remote server (a master expert module that sums up the results sent by multiple local modules). Quality of recorded signals observations allows to develop assumptions for a module that would ensure continuous monitoring of the driver's condition (signal variability). Next, the initial assumptions were translated into the BIO software module functionality:

- ability to define a target group of analyzed signals;

- ability to generate an error marker for signals exceeding the measurement range;

- ability to recognize signals outside of the ranges acceptable for a healthy person;

- ability to predefine the analysis window width - dynamically, at each function call;

- ability to predefine the frequency limit for the low-pass filter, the signal sampling frequency and the full range of reference parameters (boundaries, measurement ranges for the devices and reference values) - static, in the header file. 
The implementation discussed above allows for calculating the BIO indicator in real-time that is much faster than the time needed to register the signals for processing. Therefore, this tool ensures much deployment flexibility, in line with the assumptions for wireless result transfer (IEEE 802.11 networks) using the Vehicle Surveillance System [24]).

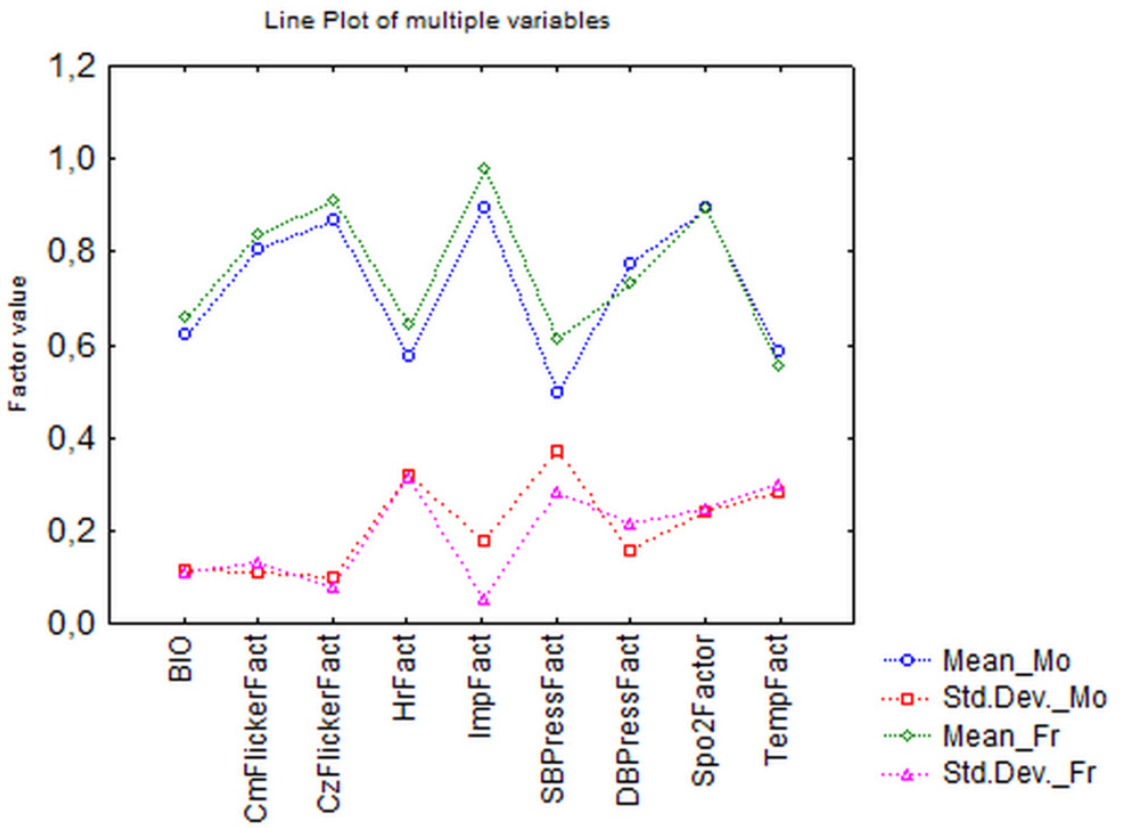

Figure 6: Correlation of the $\mathrm{BIO}$ indicator values with road conditions.

Table 2: Interpretation of the BIO indicator.

\begin{tabular}{|l|l|l|}
\hline \multicolumn{1}{|c|}{ Indicator } & \multicolumn{1}{|c|}{$\begin{array}{c}\text { Theoretical } \\
\text { interpretation }\end{array}$} & \multicolumn{1}{c|}{ Mathematical interpretation } \\
\hline$(0-0.33>$ & indisposed & $\begin{array}{l}\text { no more than five component indicators } \\
\text { may have not acceptable values }\end{array}$ \\
\hline$(0.33-0.66>$ & $\begin{array}{l}\text { partially } \\
\text { disposed }\end{array}$ & $\begin{array}{l}\text { no more than three component } \\
\text { indicators may have not acceptable } \\
\text { values }\end{array}$ \\
\hline$(0.66-1)$ & fully disposed & $\begin{array}{l}\text { no more than one component indicator } \\
\text { may have not acceptable values }\end{array}$ \\
\hline
\end{tabular}




\section{Results}

The BIO software module discussed in this paper enables monitoring the condition of a driver with delays below the analysis window width. The signal evaluation method enables easy high-level estimation of the driver's condition in terms of basic vital parameters.

The results shown in Fig. 6 show that the basic physiological parameters are different at the beginning and at the end of a driver's working week. The target $\mathrm{BIO}$ indicator, as well as a majority of component indicators, are several percent better on Friday (with the measurements taking place in the afternoon, with more fatigue) than on Monday (with the measurements taking place in the morning, after the weekend rest). The registered and analyzed condition of the participants may be interpreted as follows:

- beginning of the working week (Monday) - emotional excitations, getting accustomed to the monitoring (large number of measurement devices in the vehicle, partially requiring response/handling by the driver);

- end of the working week (Friday) - aware that this is the last day of work in the week, final task in the research, familiarity with the actions required (almost falling into routine - the route, handling on-board devices).

The third analysis shown in Fig. 7 proves a relationship between the averaged BIO indicator and the driver's age. Participants aged 26-30 showed much worse physiological condition (less than $60 \%$ of the normalized indicator value). In the 30-35 age group, the indicator was rising linearly, reaching a stable, high level (over $70 \%$ ) in the $35-45$ age group.

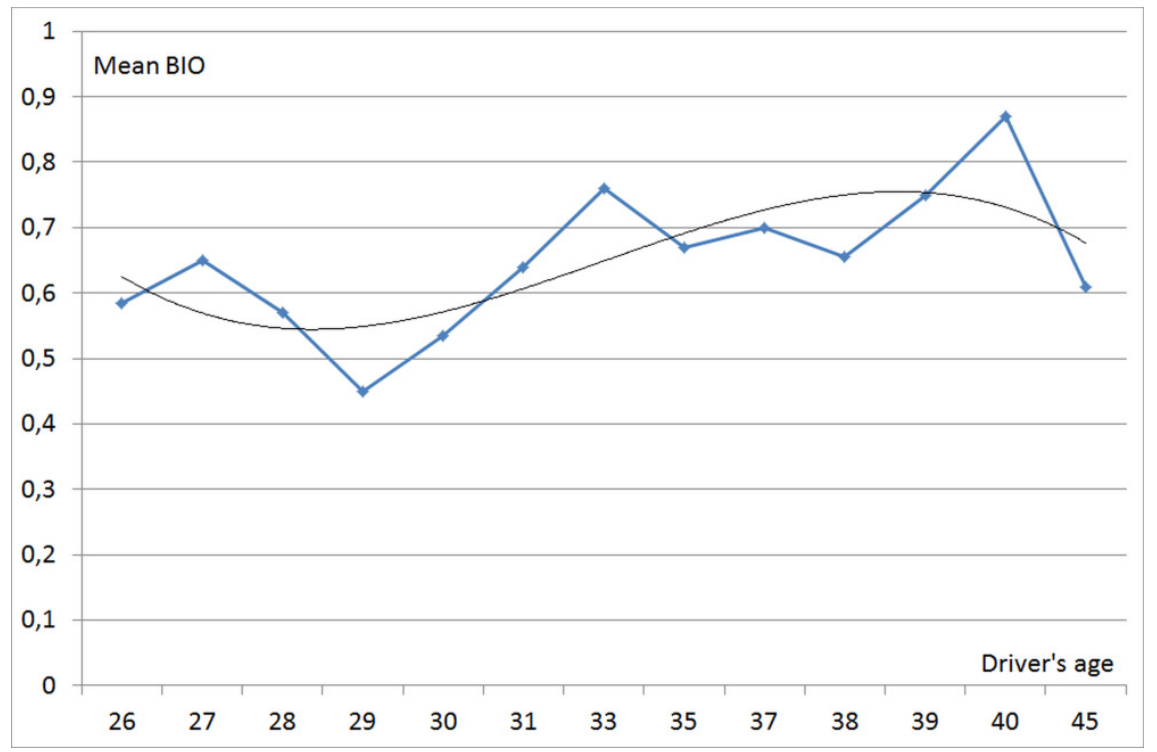

Figure 7: Correlation of the BIO indicator values with the driver's age. 


\section{Conclusions}

The analyses discussed in this paper refer to factors crucial for road traffic safety, such as: fatigue, stress, attention strain, microclimate, vision distortion, decisionmaking processes, attention-division processes, and cardiovascular system condition.

The proposed tool uses physiological signals registered during the travel to estimate the driver's condition and predisposition for continued work. The software module can be implemented on Linux hardware platforms that act as control and measurement stations. The numerical BIO indicator is calculated in real-time.

To recapitulate, the BIO software module shows unprecedented end-to-end approach to evaluating the driver's biomedical condition, based on a broad range of signals.

$\mathrm{BIO}$ indicators calculated for the group of seventeen participants make it possible to identify the impact of external conditions and the corresponding shift in the driver's condition (see Fig. 6). Moreover, the indicator calculated by the software module shows much greater ability to adjust to conditions of extended travel in the middle-aged group than in the younger group (see Fig. 7).

Elderly drivers were not included in this study. Therefore, it was impossible to draw any conclusions as to predisposition degradation due to, e.g., sudden deterioration of the physical condition or dementia (as described in [25]).

\section{Acknowledgements}

Grant sponsor: Project co-financed by the European Union using the European Regional Development Fund and by the state budget under the Innovative Economy Operational Programme.

Grant number: UDA-POIG.01.03.01-10-085/09 An integrated system for monitoring the psychophysiological condition of vehicle drivers to minimize threats in road traffic.

\section{References}

[1] Baldock, M.R.J., Mathias, J., McLean, J. \& Berndt, A., Visual attention as a predictor of on-road driving performance of older drivers. Australian Journal of Psychology, 59(3): 159-168, 2011.

[2] Newnam, S., Greenslade, J., Newton, C. \& Watson, B., Safety in Occupational Driving: Development of a Driver Behavior Scale for the Workplace Context. Applied Psychology: An International Review, 60(4): 576-599, 2011.

[3] Jeżewska, M. \& Leszczyńska, I., Badania psychologiczne kandydatów na kierowców - idea czy nakaz. Propozycja metodologii badań - głos w dyskusji. In: Horst WM, Dahlke G. Bezpieczeństwo pracy kierowców. Uwarunkowania psychologiczne i ergonomiczne. Wydawnictwo Instytutu Inżynierii Zarzadzania Politechniki Poznańskiej, 2008. 
[4] Factor, R., Yair, G. \& Mahalel, D., Who by Accident? The social morphology of car accidents, Risk Analysis 30(9): 1411-1423, 2010.

[5] Trojański, M., Anatomia stresu: przezwyciężyć stres i zmęczenie: poradnik nie tylko dla kierowców. Fundacja Akademia Transportu, 2008.

[6] Pack, A.I., Pack, A.M., Rodgman, E.A., Cucchiara, A., Dinges, D.F. \& Schwab, C.W., Characteristics of Accidents Attributed to the Driver Having Fallen Asleep. Annual Proceedings of the Association for the Advancement of Automotive Medicine, 38: 395-405, 1994.

[7] Maycock, G., Sleepiness and driving: the experience of UK car drivers. Journal of Sleep Research, 5: 229-237, 1996.

[8] Esch, T., Stefano, G.B., Fricchione, G.L. \& Benson, H., Stress in cardiovascular diseases. Medical Science Monitor, 8(5): 93-101, 2002.

[9] Blaim, J., Zdrowie kierowcy. Wydawnictwa Komunikacji i Łaczności, 2090, 1969.

[10] Wągrowska-Koski, E. \& editors, Zagrożenia zdrowia kierowców pojazdów silnikowych związane ze szkodliwymi i uciążliwymi warunkami środowiska pracy. Oficyna Wydawnicza Instytutu Medycyny Pracy im. prof. J. Nofera, 24-74, 2007.

[11] Dingus, T.A., Klauer, S.G., Neale, V.L., Petersen, A., Lee, S.E., Sudweeks, J.D., Perez, M.A., Hankey, J., Ramsey, D.J., Gupta, S., Bucher, C., Doerzaph, Z.R., Jermeland, J. \& Knipling, R.R., The 100-Car Naturalistic Driving Study, Phase II - Results of the 100-Car Field Experiment. U.S. Department of Transportation, National Highway Traffic Safety Administration, 2006.

[12] Mitas, A.W., Czapla, Z., Bugdol \& M., Ryguła, A., Rejestracja i ocena parametrów biometrycznych kierowcy dla poprawy bezpieczeństwa ruchu drogowego. Zeszyty Naukowe Politechniki Ślaskiej, Seria Transport, 66: $72-77,2010$.

[13] Dybowski, J., Ukleja-Adamowicz, M. \& Nartowicz, E., Zespół wazowagalny jako przyczyna wypadków drogowych. Folia Cardiologica, 6(4): 388-390, 1999.

[14] Siedlecka, J., Sen kierowcy w aspekcie bezpieczeństwa na drodze. Praca $i$ Zdrowie, 4, 2011. The Seventh Report of the Joint National Committee on Prevention, Detection, Evaluation and Treatment of High Blood Pressure. $U$. S. Department of Health and Human Services, National Institutes of Health, Publication 04-5230, August 2004.

[15] Miyai, N., Arita, M., Morioka, I., Takeda, S. \& Miyashita, K., Ambulatory blood pressure, sympathetic activity, and left ventricular structure and function in middle-aged normotensive men with exaggerated blood pressure response to exercise. Medical Science Monitor, 11(10): 478-484, 2005.

[16] Fan, X., Bi, L. \& Wang, Z., Detecting Emergency Situations by Monitoring Drivers' States from EEG. Proceedings of IEEE ICME, 245-248, 2012.

[17] Mahachandra, M., Yassierli, Sutalaksana, I.Z. \& Suryadi, K., Sensitivity of Heart Rate Variability as Indicator of Driver Sleepiness. IEEE SEANES, 16, 2012. 
[18] Yekhshatyan, L. \& Lee, J.D., Changes in the Correlation Between Eye and Steering Movements Indicate Driver Distraction. IEEE Transactions on Intelligent Transportation Systems, 14(1): 136-145, 2013.

[19] Conjeti, S., Singh, R.R. \& Banerjee, R., Bio-inspired Wearable Computing Architecture and Physiological Signal Processing for On-road Stress Monitoring. Proceedings of the IEEE-EMBS BHI, 479-482, 2012.

[20] Różanowski, K., Sondej, T., Radomski, T. \& Piotrowski, Z., Wielozadaniowy system monitorowania sygnałów fizjologicznych i środowiskowych. Elektronika konstrukcje, technologie, zastosowania. Wydawnictwo Sigma-Not, 9: 85-91, 2007.

[21] Różanowski, K., Piotrowski, Z., Sondej, T., Sawicki, K. \& Głowacki, M., Wireless Driver and Vehicle Surveillance System Based on IEEE 802.11 Networks. Communication Technologies for Vehicles, LNCS, 7266: 57-67, 2012.

[22] Piotrowski, Z. \& Różanowski, K., Robust Algorithm for Heart Rate (HR) detection and Heart Rate Variability (HRV) Estimation. Acta Physica Polonica A, Acoustic and Biomedical Engineering, 118(1): 131-135, 2010.

[23] Garay, A, Measuring and evaluating digital watermarks in audio files, 45, 2002.

[24] Różanowski, K., Sondej, T., Piotrowski, Z. \& Sawicki, K., Architecture of Car Measurement System for Driver Monitoring. Communication Technologies for Vehicles, LNCS, 7266: 68-79, 2012.

[25] Martin, A.J., Marottoli, R. \& O'Neill, D., Driving assessment for maintaining mobility and safety in drivers with dementia. Cochrane Database of Systematic Reviews, 2009.

[26] Benetos, A. et al., A Decrease in Diastolic Blood Pressure Combined With an Increase in Systolic Blood Pressure Is Associated With a Higher Cardiovascular Mortality in Men. Journal of the American College of Cardiology, 35(3), 2000.

[27] Grzegorczyk, A., Pełech, A., Sompoliński, M. \& Szczęśniak, S., Mikroklimat sal widowiskowych. Polski Instalator, 10: 64, 2004.

[28] Lynn-McHale, D.J. \& Carlson, K.K., AACN Procedure manual for Critical Care, Fourth Edition. W. B. Saunders, January 15: 77, 2001.

[29] Veitch, J.A., Light source flicker: When and how does it affect us? Conference: Voices for SSL Efficiency DOE Solid-State Lighting Market Introduction Workshop, Philadelphia, 2010.

[30] Willis, A.K. et al., Life course trajectories of systolic blood pressure using longitudinal data from eight UK cohorts. PLoS Medicine, June, 2011.

[31] Zielonka, M., Nasze własne c.o., czyli parę słów o termoregulacji. Zaklad Biofizyki Obliczeniowej $i$ Bioinformatyki, Wydziat Biochemii, Biofizyki $i \quad$ Biotechnologii, Uniwersytet Jagielloński, www: http://bioinfo.mol.uj.edu.pl/articles/Zielonka06, 2011. 